\title{
STUDENTS' ATTITUDE TOWARD THE USE OF WATTPAD IN READING COMPREHENSION
}

\author{
Rohani Ganie, Khairunnisa Audi Miranda, Muhammad Yusuf \\ Universitas Sumatera Utara (USU), Medan, Indonesia \\ E-mail: ganierohani@gmail.com
}

Received: 2021-11-01

Accepted: 2021-12-13

\begin{abstract}
This study attempts to seek what components of reading are affected by reading Wattpad and how the students' attitudes towards the use of Wattpad for reading. This research used a descriptive qualitative method. This research is also supported by the theory of reading attitude proposed by McKenna, et.al. The data for this study were collected from two sources, namely a close-ended questionnaire to 20 English Literature students of Universitas Sumatera Utara and supported by interview with 5 out of 20 selected respondents. The results of this study indicate two main things, namely: (1) Vocabulary is the component of reading that is most affected. As many as $40 \%$ of respondents chose vocabulary as the most affected reading component, $35 \%$ of respondents chose comprehension ability, $15 \%$ of respondents chose reading fluency and $10 \%$ of respondents chose phonemic awareness. (2) It was found that 10 respondents were judged to show a positive attitude towards the use of Wattpad, 6 respondents showed a neutral attitude and 4 respondents showed a negative attitude towards the use of Wattpad.
\end{abstract}

Keywords: Reading Skill, Students' Attitude, Vocabulary, Comprehension

\section{Introduction}

In English, there are four language skills, they are listening, speaking, reading, and writing. One of the most important language skills that must be mastered by students is reading. Reading is a window to the world. By reading, readers will get a lot of very useful information, whether new or what they have read before. According to Alfassi (2004), reading is a complex cognitive activity essential for sufficient functioning and for obtaining information in modern society. For some people, reading can be challenging if the material is unfamiliar, technical, or complex. One of the challenging reading skills is comprehension. Reading can help develop the thinking process of the reader and it creates judgment thinking. Yamashita (2013) states that accompanied by feelings and emotions, reading attitude is a state of mind accompanied by feelings and emotions that makes reading more or less probable. In conclusion, reading attitude is an internal aspect that can help the learner develop and have live long reading skills. Currently, with the development of technology and information, there are a lot of media that can make it easier for readers to find the reading material they need. Then there is also the presence of online reading applications that allow users to read and/or write stories by the author himself and can be read by various people around the world. Wattpad is one of the many online reading applications used by the public. The Wattpad application is the result of collaboration 
Students' Attitude Toward The Use of Wattpad in Reading Comprehension, Rohani Ganie, Khairunnisa Audi Miranda, Muhammad Yusuf

between Allen Lau and Ivan Yuen. This app is based in Toronto, Canada. According to Tirocchi (2018), the Wattpad application is quite influential in the world community. In fact, according to Mawardi (2018), this application also affects the Indonesian publishing industry where there are many novels labeled Wattpad. Thus, many successful book writers started their careers from Wattpad. This research was conducted on 20 English literature students at Universitas Sumatera Utara who are Wattpad users. This research was conducted on English Literature students at Universitas Sumatera Utara because research like this had never been done before on English Literature students at Universitas Sumatera Utara.

\section{Literature Review}

\subsection{Reading}

According to Brown (2001), there are four skills that are identified as very important in the teaching and learning process; listening, speaking, reading, and writing. Reading is one of the important language skills. Eskey and Dubin (1986: 12) states that reading is a receptive language process. Alyousef (2006: 64) claims that reading can be seen as an "interactive" process between a reader and a text which leads to automaticity or (reading fluency).

\subsubsection{The Importance of Reading}

There is much importance of reading because reading is one of the positive activities that many people love. The first one is reading can reduce anxiety. Then, reading can improve brain development. Moreover, by reading a lot, of course, someone's knowledge will increase too. Reading can also improve a person's memory.

\subsubsection{The Aim of Reading}

In the theory put forward by Tarigan (2008), the aim of reading is 7 (seven), namely; a) Reading for details or facts $b$ ) Reading for main ideas $c$ ) Reading for sequence or organization d) Reading for inference e) Reading to classify f) Reading to evaluate g) Reading to compare or contrast

Abidin gives another opinion about the aims of reading. Abidin (2010: 9) provides 3 reading aims, namely: a) Reading for knowledge b) Reading to earn c) Reading for entertainment

\subsubsection{Types of Reading}

Based on the purpose of the readers, reading is categorized into some types. According to Brown (2004: 186 - 187) reading is categorized into three types, namely academic reading, job-related reading, and personal reading.

\subsubsection{Methods of Reading}

Basically, the reading method is divided into 2, namely the intensive reading method and the extensive reading method. The Intensive Reading Method is a reading activity that is carried out seriously to get some information. Extensive reading is a type of reading activity that is carried out carefully with a variety of reading sources, namely novels, magazines, newspapers, web pages, or any other reference material. This fluency activity is mainly involving understanding. The main ways are: a) Skimming, is a reading technique used when we want to find the main idea as a whole from a book. b) Scanning, is a reading technique used to get specific information quickly and accurately from a book. 


\subsection{Reading Skill}

According to Perfetti (2001), reading skill is an individual's standing on some reading assessment. Meanwhile, Snow states that reading skill is the process of simultaneously extracting and constructing meaning through interaction and involvement with written language. The National Reading Panel (2000) states that there are 5 essential components needed to make up the process of reading skill. These 5 essential components namely: Fluency, Vocabulary, Comprehension, Phonemic Awareness, and Phonics.

\subsection{Attitude}

Attitude is our evaluation of a person, an idea, or an object. Attitudes are favorable or unfavorable: positive or negative. Also, they have three components: an affective component (feelings), a behavioral component (the effect of the attitude on behavior), and a cognitive component (belief and knowledge).

\subsubsection{Characteristics of Attitude}

Perloff (2003) defines characteristics of attitudes into three, they are: a) Attitudes are learned. b) Attitudes are global. c) Attitudes influence thought and action.

\subsubsection{Factors Influencing Students' Attitude}

Azwar (2013) proposes some factors that influence students' attitudes; a) Personal experience. b) Influence others that are considered important. c) Influence of culture. d) The mass media. e) Institute of Education and Religious Institutions. f) Emotional Factors.

\subsection{Reading Attitude}

According to Mathewson (1994), there are three central elements of reading attitude, namely feelings about reading, readiness to engage in the act of reading, and beliefs about reading. These three attitudes' central elements that were expressed by Matthewson combine three approaches commonly used to define attitudes in the psychological literature namely affective, conative, and cognitive. According to McKenna, Kear, \& Ellsworth (1990), three main factors that influence attitude are: (a) beliefs about results, (b) beliefs about other people's expectations with respect to one's motivation to conform to those expectations, and (c) the results of specific reading incidents.

\subsection{Online Reading}

In the past, before the development of technology, offline reading was very popular among the public. In online reading, readers read the information on the World Wide Web in various formats, including texts, hyperlinks, animations, pictures, videos, and sounds. In online reading, a hypertextual form of reading is provided. The internet provides access information in a large amount, so finding relevant information in an effective way requires new online reading comprehension skills and strategies. Then, Coiro and Dobler (2007) show that there are also some important differences in online and offline reading even though the reading process is similar.

\subsection{Wattpad}

Wattpad (www.wattpad.com) is one of the online reading media. Wattpad is a website and application service based in Toronto, Canada. Wattpad is a collaboration between Allen Lau and Ivan Yuen which launched in 2007. Wattpad provides a forum for writers to express 
Students' Attitude Toward The Use of Wattpad in Reading Comprehension, Rohani Ganie, Khairunnisa Audi Miranda, Muhammad Yusuf

or promote their work and can be read by people from all over the world. Even though there are approximately 50 languages available, $77 \%$ of the stories on Wattpad are written in English.

\section{Research Method}

In this research, the researchers used a descriptive qualitative method. The descriptive approach was adopted for collecting data on students' reading attitudes. In accordance with the characteristics of the data required in this study, the data collection techniques used are questionnaire and interview. In this study, researchers recorded all answers from respondents as they are. Here, researchers gave the questionnaire to 20 students of English literature at Universitas Sumatera Utara based on Cresswell's (2007) opinion about grounded theory. Creswell states in a grounded theory study, the researcher chooses participants who can contribute to the development of the theory. Creswell (2007) recommended that a grounded theory study should include 20 to 30 participants to cover a wide range of breadth; a smaller sample could be used with various data collection tools. Researchers also conducted the interviews with 5 selected students from the 20 respondents. The researchers used simple random sampling in selecting 5 students who participated in the interview. Creswell (2012: 142) explains that a slight variation of the simple random sampling procedure is to use systematic sampling. The function of simple random sampling is to choose individuals became sample who will be representative of the population.

\section{Results and Discussion}

To clarify the presentation of the data display, this section is divided into 2 parts to obtain the results of the number one research question, namely 'What are reading components affected by reading Wattpad?' and research question number two, namely 'How are students' attitudes towards the use of Wattpad in reading?'

\subsection{Reading Components Affected by Reading Wattpad}

In this section, respondents were given 5 questions to find out their response to any reading components that have affected their reading skills.

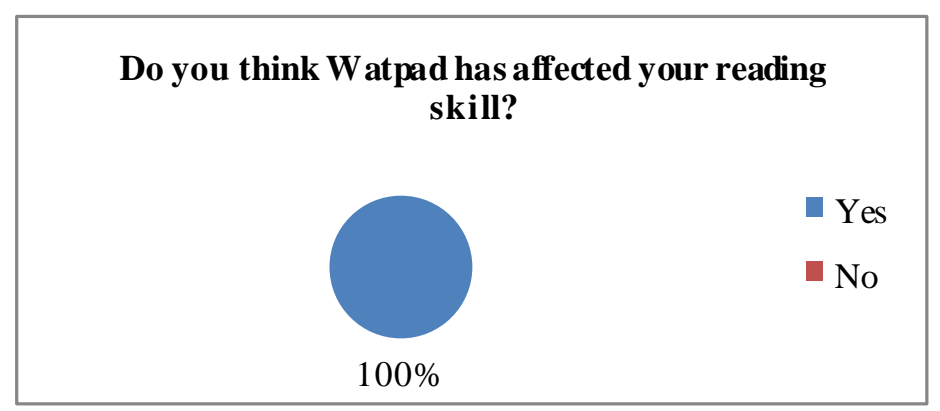

Figure 1. Question 1

100 percent of respondents answered 'Yes' to the first question in this section which is 'Do you think Wattpad has affected your reading skill?' This means that all of the respondents agree that reading Wattpad has had an effect on their reading skills. They said:

Because basically, Wattpad is an application for reading, so indirectly reading Wattpad often will affect my reading skills (R1) 
Because by reading Wattpad, I often read so that my reading skills are increasing (R5)

From the observations above, it can be concluded that Wattpad has indeed affected the reading skills of its readers. Since Wattpad is an application for reading, it is very possible for Wattpad to influence the reading skills of its readers.

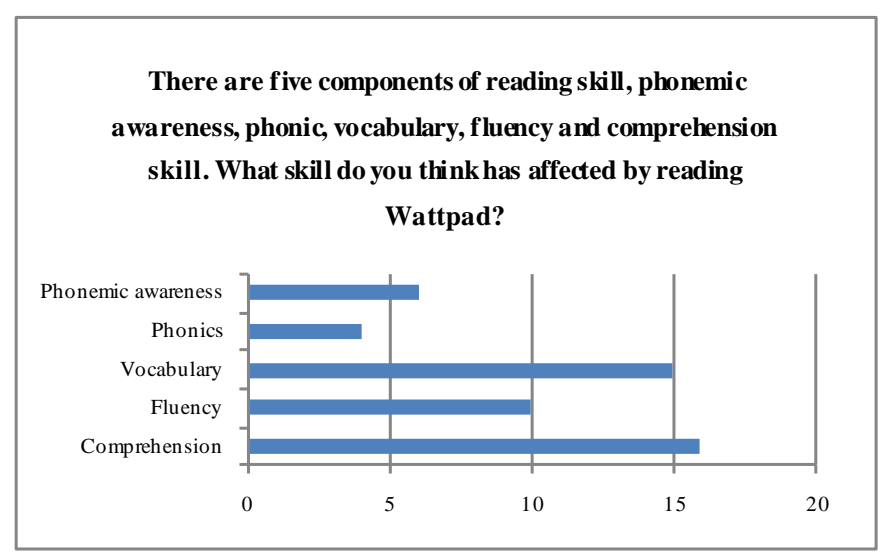

Figure 2. Question 2

This second question aims to get information about what skills according to respondents have been affected by reading Wattpad. In this question, respondents may choose more than one skill that they think is most affected by reading Wattpad. Based on the respondents' answers, it can be seen that phonemic awareness was selected 6 times, phonics was selected 4 times, vocabulary was selected 15 times, fluency was selected 10 times and comprehension skill was selected 16 times. The 3 choices with the most results are comprehension, vocabulary, and fluency. They said:

Because with the variety of stories on Wattpad, of course, I found a lot of new vocabulary, as well as reading frequency, will definitely affect my fluency in reading. Then, my comprehension ability will also be affected because basically the purpose of reading is to understand the contents of the reading $(\mathrm{R} 1)$

Because there are many new dictions that I found on Wattpad so that it adds to my vocabulary (R3)

I chose vocabulary because there are so many new vocabularies like slang that I found on Wattpad. Then, fluency because I often read while reciting what I read. And then also comprehension, because from reading I feel I have to understand the context of the text I read (R4)

My vocabulary increases because the more I read, the more new vocabulary I encounter. Also, the more often I read stories on Wattpad, it will train my comprehension of the new vocabulary I encounter and understanding the context of the text I read (R5)

From the results of further observations, it can be concluded that many students choose comprehension skills because according to them in reading, of course, they must have good 
Students' Attitude Toward The Use of Wattpad in Reading Comprehension, Rohani Ganie, Khairunnisa Audi Miranda, Muhammad Yusuf

comprehension skills to understand the meaning of the stories they read. And indirectly, reading Wattpad will really train and ultimately affect their comprehension skills as readers. Their vocabulary also increases because of the variety of new dictions they find from the stories they read on Wattpad. Then fluency, because not a few people read while reciting what they read to hone their pronunciation skills for a word or sentence.

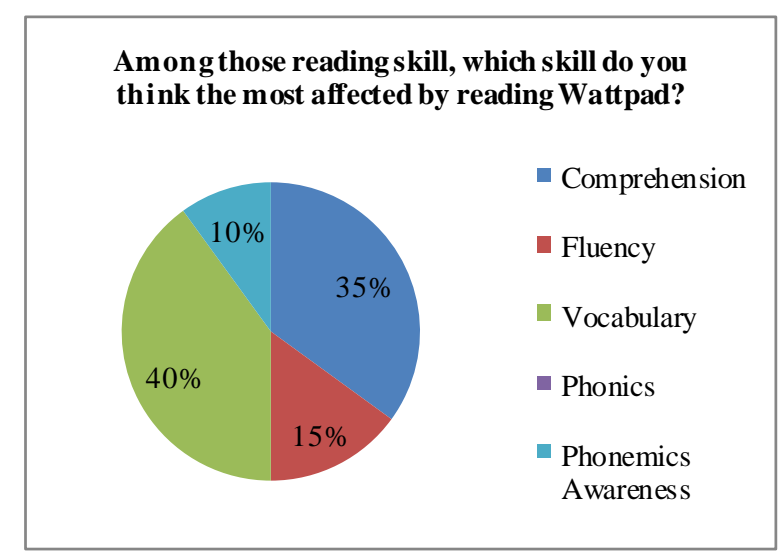

Figure 3. Question 3

The graph above shows the answers to the question of which reading skills according to respondents are most affected by reading Wattpad. In fact, the most, namely 8 people or $40 \%$ of the respondents stated that vocabulary is the skill most affected by reading Wattpad. Then 7 people or $35 \%$ of the respondents stated that comprehension skills were the most affected by reading Wattpad. Then, 3 people, or $15 \%$ of the respondents chose fluency skill as the skill most affected by reading Wattpad. Also, 2 people or $10 \%$ of the respondents stated that phonemic awareness is the skill most affected by reading Wattpad. And none of the respondents stated that phonics was the skill most affected by reading Wattpad. Finally, it can be concluded that vocabulary is the most affected skill by reading Wattpad. They said:

Vocabulary, because I think the text in any language is important for us to understand the meaning of the words used by the author. So this greatly affects my vocabulary skills (R2)

Vocabulary, because before I was able to buy novels, Wattpad became one of my mediums for finding new dictions that greatly expanded my vocabulary (R3)

From the interview, it can be seen that many of the respondents agree that Wattpad has helped a lot to improve their Vocabulary knowledge because of the choice of vocabulary or diction used by the author. However, the number of respondents who chose comprehension as the most affected skill was only 1 point or $5 \%$ different from Vocabulary. 2 out of 5 respondents interviewed said:

Comprehension, because I think when reading I am indirectly required to first understand what the text means (R1)

Comprehension, because when I read I really feel compelled to understand every text I read (R5) 
From the results of the interviews above, it can be concluded that they agree that when reading, it is very important to understand the meaning of the text being read. Therefore, they agree that reading Wattpad also affects their comprehension skills.

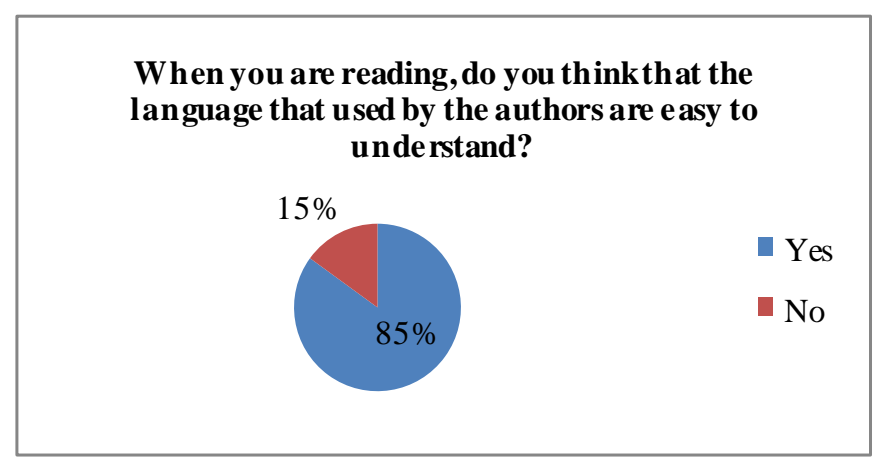

Figure 4. Question 4

The chart shows respondents' answers to questions about whether the language or vocabulary used by the author is easy to understand or not. A total of 17 people or $85 \%$ of the respondents agreed that the language used by the authors in the stories they read on the Wattpad application is easy to understand. In the interview they said:

Yes, because most of the texts on Wattpad are light stories with light vocabulary (R1)

Yes, because many stories I found on Wattpad use simple and light diction (R3)

Yes, the language used is mostly quite light (R4)

Yes, because the language written is not complicated, so it is very easy for me to find out and understand the plot of each story on Wattpad (R5)

4 out of 5 respondents who were interviewed agree that the language used by the authors in the stories they read on Wattpad is easy to understand because basically the stories on Wattpad are fairly light stories. Of course, it allows most writers to use everyday language that is easy to understand in the writing of the stories they publish.

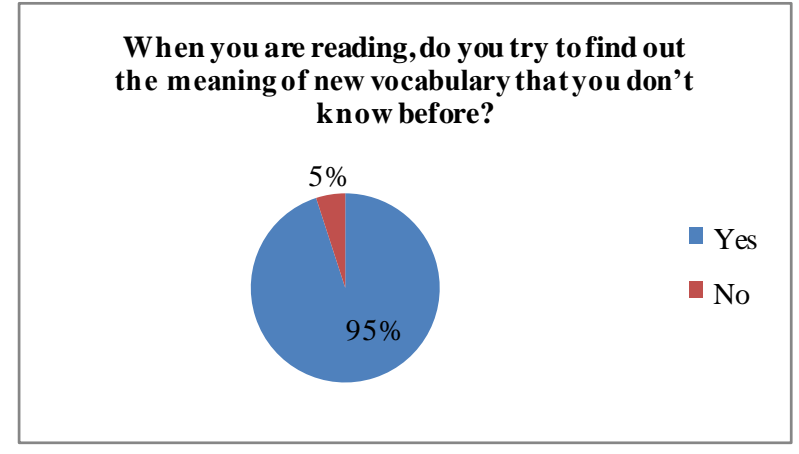

Figure 5. Question 5

From the chart above, it can be seen that as many as 19 people, or $95 \%$ of the respondents find out the meaning of each new vocabulary they find, which they did not know before. They said: 
Students' Attitude Toward The Use of Wattpad in Reading Comprehension, Rohani Ganie, Khairunnisa Audi Miranda, Muhammad Yusuf

Yes, because it can help me to understand better the content of the text I read (R1)

Yes, because I think it is very useful to find out the meaning of this new vocabulary for my next interest (R2)

Yes, because basically, I am a person who has a high curiosity so it is important for me to understand the meaning of every word I read (R3)

Yes, because it is important for me to know the meaning of the text that I do not know to understand the context of the text I read (R4)

Yes, because in order to understand a story, I am required to understand every new vocabulary I encounter (R5)

It can be concluded that all interviewed respondents agree that it is very important to find out the meaning of vocabulary that they did not know before. They do search the meaning because by that there is no misunderstanding of the actual meaning of the sentence they are reading.

\section{Students' Attitudes towards the Use of Wattpad in Reading}

In this section, the respondents' answers to the second section of the questionnaire will be described. In this section 2, respondents were given 10 questions to find out their attitude towards the use of Wattpad in reading.

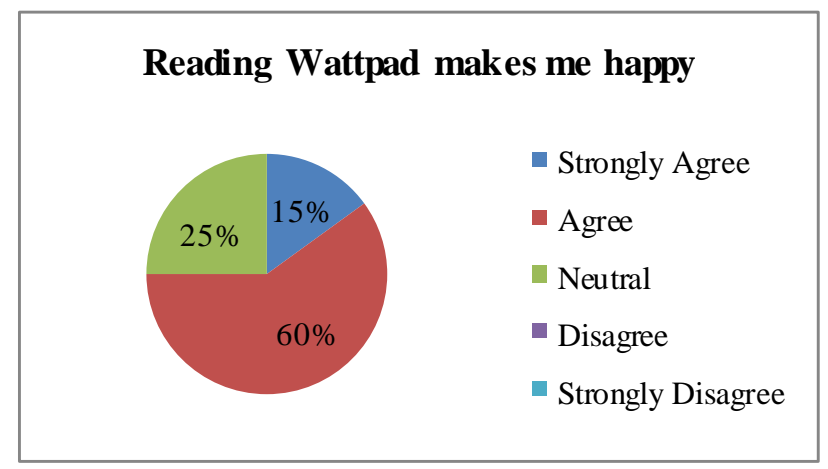

Figure 6. Question 6

The chart above contains opinions from the statement that Wattpad can make the readers feel happy while reading. This statement refers to the affective aspect of reading attitude. As many as 12 people or $60 \%$ of the respondents agreed that Wattpad can make them feel happy. As many as 3 people or $15 \%$ of the respondents strongly agree that Wattpad can make them feel happy. 5 people or $25 \%$ of the respondents stated neutral to this statement. This means that no one disagrees with this statement. Those who agree said that:

Strongly agree, because, in my opinion as an escape from the daily grind which is quite stressful, of course, Wattpad really makes me happy or is known as a mood booster (R2)

Strongly agree, because I found a lot of entertaining stories on Wattpad (R4) 
Agree because the more I read the more I'm curious about the storyline and that makes me happy (R5)

From the results of the statements and interviews, it can be concluded that Wattpad can indeed make its readers feel happy. This can be caused by the variety of stories on Wattpad that can entertain readers. Wattpad can also help its readers feel happy because reading Wattpad can be a good escape from their busy daily life that makes them tired.

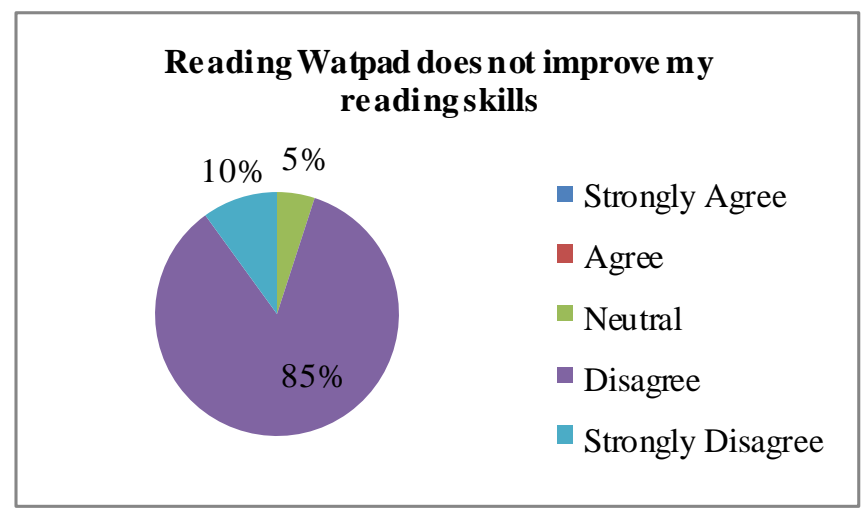

Figure 7. Question 7

The chart above provides the results of responses from respondents to the statement that Wattpad does not improve the reading skills of its readers. This statement refers to the affective aspect of reading attitude. A total of 17 respondents or $85 \%$ of respondents disagreed that Wattpad did not improve their reading skills as readers. 2 people or $10 \%$ of respondents stated strongly disagree with the statement. And there is 1 person or $5 \%$ of the respondents chose neutral with this statement. In interviews, those who disagree said:

Disagree, because I think Wattpad improves my reading comprehension skills (R1)

Strongly disagree, because by reading Wattpad a lot I am used to speeding reading and choosing which information is important and not important and I think that is one of my reading skills which has improved because of reading Wattpad $(\mathrm{R} 2)$

Disagree, because as I said, Wattpad is quite helpful for me to improve my reading skills by increasing my vocabulary and comprehension as well (R3) Disagree, because based on my experience, my vocabulary increases because of reading Wattpa (R4)

Disagree, because reading Wattpad has improved my reading skills (R5)

From the results above, it can be concluded that reading Wattpad improves their reading skills. Some say that their comprehension skills have improved because of reading stories on Wattpad. Not a few of them also agree that reading stories on Wattpad have improved their vocabulary knowledge. 


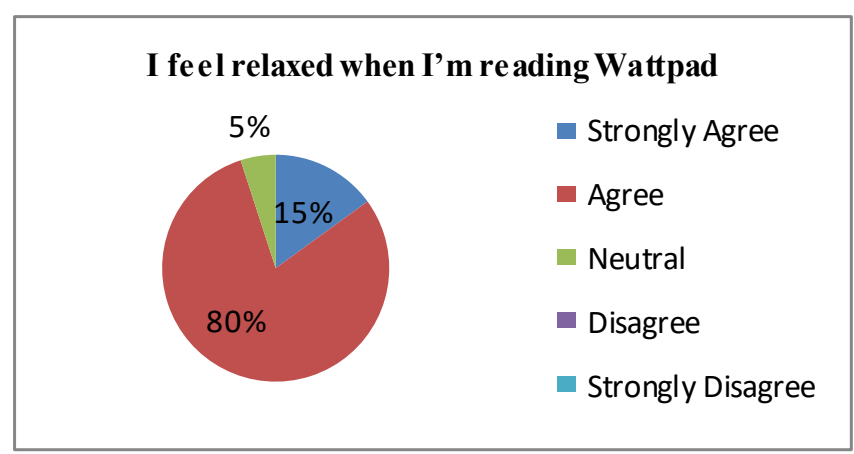

Figure 8. Question 8

The chart above provides the results of respondents' responses to the statement that readers feel relaxed when reading Wattpad. This statement refers to the affective aspect of reading attitude. 16 people or $80 \%$ of respondents agree that reading Wattpad can make readers feel relaxed while reading. 3 people or $15 \%$ of the respondents strongly agree that Wattpad can make them feel relaxed. And 1 person or $5 \%$ of the respondents stated neutral in this statement. Those who agree said:

Agree, because the stories on Wattpad are quite light, so I think it makes me relax in the midst of my busy life (R1)

Agree, because I usually read Wattpad in my spare time in the middle of my busy life, and Wattpad is quite helpful in making me feel more relaxed (R2)

Agree, because reading on Wattpad is quite light and I don't feel like I have to rush to finish reading it (R3)

Agree, because I read Wattpad in my spare time and it's perfect for relaxing me (R5)

From the results of the interview above, it can be concluded that Wattpad can indeed make its readers feel more relaxed. This can be because readers usually read Wattpad to fill their leisure time in the midst of their busy lives. Moreover, the stories on Wattpad are light enough that they are suitable for reading while relaxing.

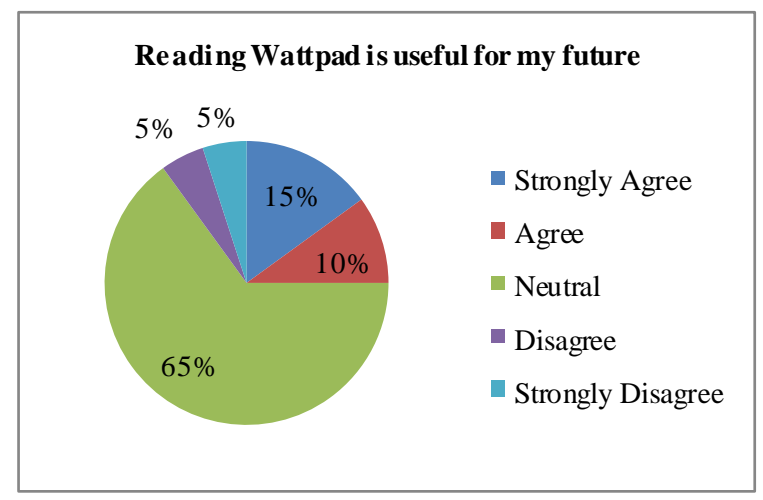

Figure 9. Question 9 
In the graph above, it can be seen the respondents' responses to the statement that reading Wattpad is useful for my future can be seen. This statement refers to the affective aspect of reading attitude. Turns out, 13 people, or $65 \%$ of respondents stated neutral to this statement. 3 people or $15 \%$ of the respondents stated strongly agree with this statement. 2 people or $10 \%$ of respondents agree with the statement that Wattpad is useful for the future. Then 1 person or $5 \%$ of respondents disagreed if Wattpad is useful for their future. Then 1 more person or the remaining $5 \%$ of respondents stated strongly disagree with this statement. Those who declared neutral said:

Neutral, because it's actually not very useful for the future but still has benefits in my reading skills (R1)

Neutral, because the content of the story from Wattpad is more for entertainment, but it is quite useful to increase my reading skills (R4)

Neutral, because my purpose of reading Wattpad is just to fill my spare time (R5)

It can be concluded from those who stated that they were neutral that the stories on Wattpad which were quite light were only able to provide entertainment benefits to them but still affected their reading skills. However, they stated that the benefits of Wattpad for them only ended there, not for the future.

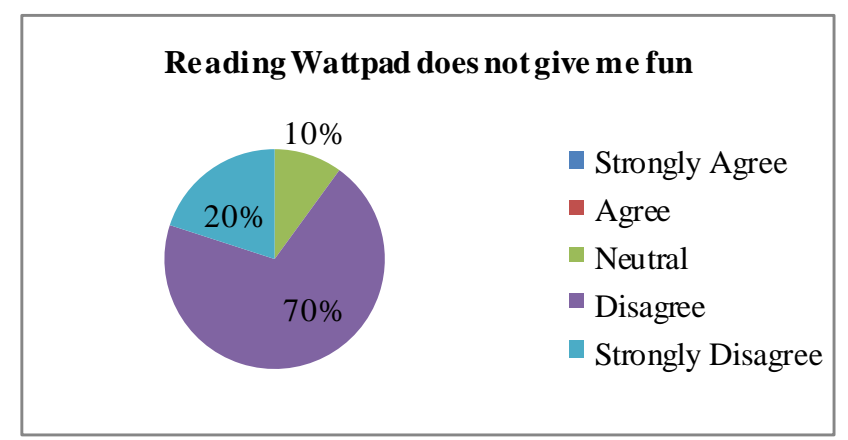

Figure 10. Question 10

This graph gives the results of respondents' responses to the statement that reading Wattpad does not give me fun. This statement refers to the affective aspect of reading attitude. As many as 14 people or $70 \%$ of the respondents disagreed with the statement that reading Wattpad does not give them fun. As many as 4 people or $20 \%$ of the respondents stated that they strongly disagreed with this statement. Then as many as 2 people or $10 \%$ of the respondents stated neutral to this statement. Those who disagree said that:

Strongly disagree, because Wattpad has always been my escape and my break from busyness, so Wattpad really makes me happy(R2)

Disagree, because if you find it interesting reading, Wattpad can make me feel excited and happy (R3)

Strongly disagree, because like I said, I read a lot of the stories and find them entertaining and enjoyable (R4)

Disagree, because I feel happy when I read Wattpad (R5) 
Students' Attitude Toward The Use of Wattpad in Reading Comprehension, Rohani Ganie, Khairunnisa Audi Miranda, Muhammad Yusuf

From the respondents' statements above, it can be concluded that those who disagree think that Wattpad gives them fun. This is because there are many interesting stories on Wattpad which they find very entertaining and enjoyable. Of course, this makes the reader feel happy.

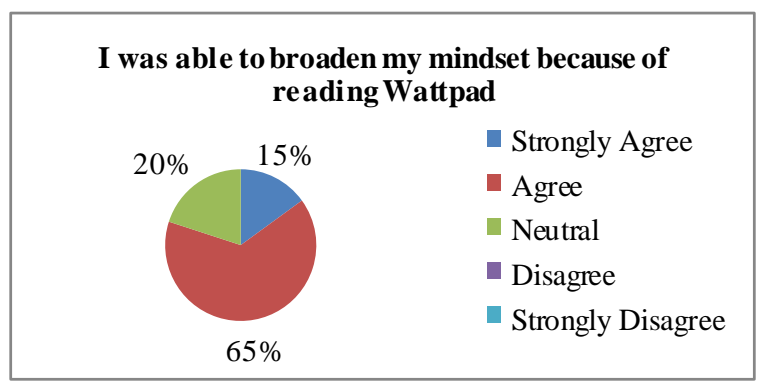

Figure 11. Question 11

The graph above shows the results of respondents' responses to the statement that Wattpad can expand the mindset of its readers. This statement refers to the cognitive aspect of reading attitude. As many as 13 people or $65 \%$ of respondents agree that reading Wattpad can expand their mindset. Then as many as 3 people or $15 \%$ of the respondents stated strongly agree with this statement. Then there are 4 people or $20 \%$ of the respondents stated neutral to this statement. They said:

Agree, because many Wattpad stories I read gave me a new perspective and it helped broaden my mindset (R1)

Strongly Agree, because many stories or events written on Wattpad make me see from various sides so that it also affects my mindset (R2)

Agree, because I think on Wattpad the stories are diverse and not about just one topic, and usually make me think positively and negatively (R3)

Agree, because I feel that I know a lot of different mindsets than I used to because of reading Wattpad (R4)

Agree, because Wattpad has different backgrounds and plots, so it makes me think about new things (R5)

From the respondents' statements in the interview above, it can be concluded that they agree that Wattpad can help expand their mindset. This can be caused by the various genres, settings, and problems that exist in the stories on Wattpad. Of course, it can provide a new perspective for the reader thus broadening their mindset.

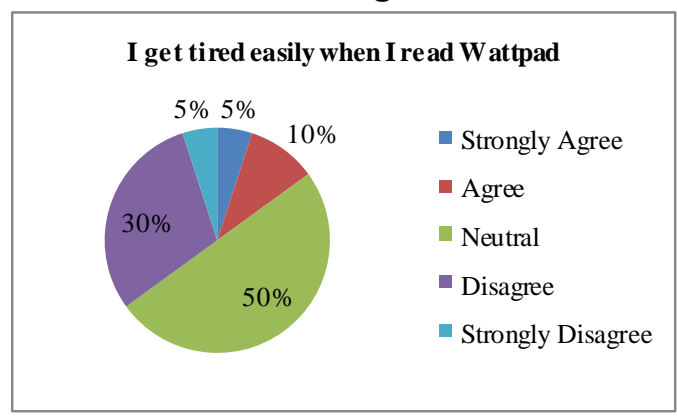

Figure 12. Question 12 
The graph above provides information on respondents' responses to the statement I get tired easily when reading Wattpad. This statement refers to the conative aspect of reading attitude. A total of 10 people or $50 \%$ of respondents stated neutral to this statement. A total of 6 people or $30 \%$ of the respondents stated that they disagree with this statement. Then 2 people or $10 \%$ of respondents agree with this statement. And also there is 1 person or $5 \%$ of the respondents stated strongly disagree with this statement. And there is also 1 person or $5 \%$ of the respondents stated strongly agree with this statement. Those who declared neutral said:

Neutral, because reading Wattpad from a cellphone is enough to make my eyes tired but I'm not bothered by it (R1)

Neutral, because sometimes what makes me stop reading is not because I'm tired, but because I have other activities to do, or have spent too much time there (R4)

From the results of the interview above, those who stated that they were neutral said that in fact they did not feel tired from reading the story, but rather their eyes were tired from staring at the phone screen too much. Then, there is enough when they have read too much.

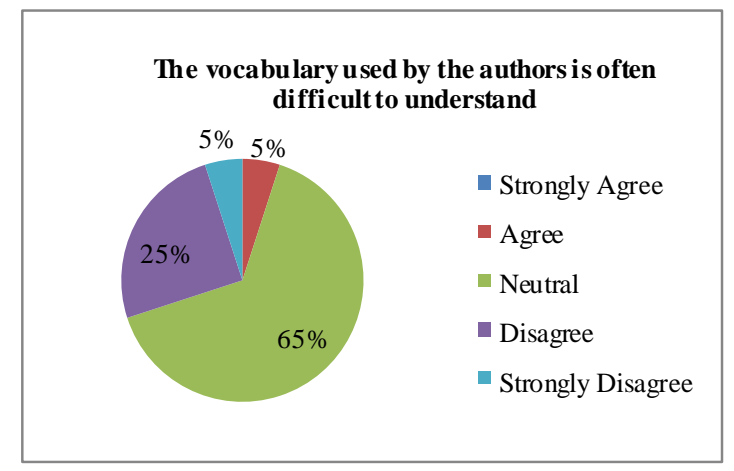

Figure 13. Question 13

The graph above shows the respondents' responses to the statement that the vocabulary used by the authors on Wattpad is often difficult to understand. This statement refers to the affective aspect of reading attitude. A total of 13 people or $65 \%$ of the respondents stated neutral to this statement. As many as 5 people or $25 \%$ of the respondents stated disagree if the vocabulary used by the authors is often difficult to understand. Then as many as 1 people or $5 \%$ of the respondents agreed with the statement. And there is 1 person or $5 \%$ of the respondents stated that they strongly disagree with the statement that the vocabulary used by the authors is often difficult to understand. Those who declared neutral said:

Neutral, because not all of the vocabulary is difficult, but there are still some vocabularies that are difficult to understand (R1)

Neutral, because I think it depends on the genre of the story being read. Like sci-fi which usually uses more difficult and scientific language and romance uses a more relaxed one (R2) 
Students' Attitude Toward The Use of Wattpad in Reading Comprehension, Rohani Ganie, Khairunnisa Audi Miranda, Muhammad Yusuf

Neutral, because I think some words are difficult to understand and I feel sometimes it's a bit of a waste of time when I find new vocabulary and have to look for meaning then I try to understand the meaning of that one word by reading the whole sentence. (R4)

Neutral, because I think it depends on the genre of the story I read (R5)

From the results of interviews with respondents who stated that they were neutral above, it can be concluded that the difficulty of the vocabulary they find depends on the genre of the story they are reading. For example, stories in the romance genre usually use light vocabulary and sci-fi stories usually use heavier and more scientific vocabulary.

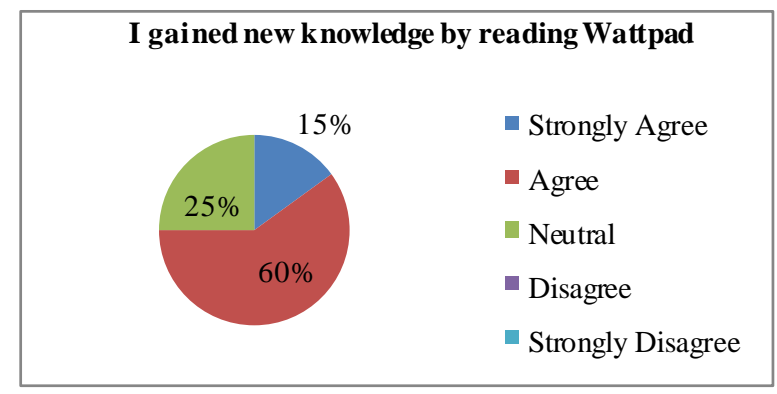

Figure 14. Question 14

The graph above provides information about respondents' responses to the statement that reading Wattpad has given readers new knowledge. This knowledge can be as simple as the knowledge that is useful in everyday life or other knowledge. This statement refers to the cognitive aspect of reading attitude. A total of 12 people or $60 \%$ of the respondents agreed with the statement. And also 3 people or $15 \%$ of the respondents stated strongly agree that they gained new knowledge by reading Wattpad. Then as many as 5 people or $25 \%$ of the respondents stated neutral with this statement. Those who agree say:

Strongly agree, because many Wattpad stories, although light, still provide new knowledge about anything, for example as simple as personal life (R2)

Agree, because many Wattpad stories describe the setting of a place that I have never come before, and sometimes they often show the characteristics of the place that is the setting, and this of course adds to my knowledge (R3)

Strongly agree, because I found a lot of new knowledge such as about stereotypes, or the culture of the story's setting (R4)

Agree, because I got a lot of knowledge from reading Wattpad stories (R5)

From the interview answers of those who agree that they get new knowledge by reading Wattpad, it can be concluded that the many stories with various backgrounds on Wattpad add new knowledge to their readers. Readers feel that they have found new knowledge about culture and stereotypes from the background of the stories they read. There are also those who feel that finding new knowledge is as simple as daily life from the stories they read on Wattpad. 


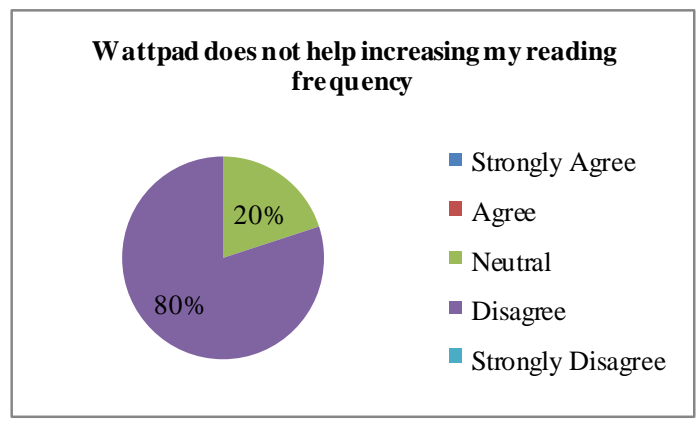

Figure 15. Question 15

In the graph above, there are responses from respondents to the statement that Wattpad does not help increase their reading frequency. This statement refers to the conative aspect of reading attitude. As many as 16 people or $80 \%$ of the respondents stated that they disagree if Wattpad did not help increase their reading frequency. And 4 people or $20 \%$ of the respondents stated neutral with this statement. Those who disagree said:

Disagree, because in my opinion, since reading Wattpad, I have read more often because the reading is quite interesting (R1)

Disagree, because by reading Wattpad I become very accustomed to reading, even when I am waiting for a story that I am waiting for update, I become thirsty and look for other readings such as in novels or other media (R2)

Disagree, because I feel a little more diligent in reading, especially if I find interesting and exciting stories (R3)

Disagree, because I find a lot of interesting stories on Wattpad, so it makes me read more often (R4)

Disagree, because when reading Wattpad my reading frequency has greatly increased (R5)

From the results of the interviews above, it can be concluded that respondents feel that reading Wattpad actually increases their level of reading frequency. This can be due to the many interesting stories they find on Wattpad and this makes them want to read more often. Some even stated that reading had become his habit so that if he couldn't find suitable reading on Wattpad, he looked for reading in other media.

After presenting the data from the questionnaire, the researchers will present data related to determining the attitude of the respondents towards the use of Wattpad in reading. This assessment was carried out by the author on the respondents' responses in section 2 of the questionnaire. The statements given are 10, 5 of which are positive statements and 5 of them are negative statements. In positive question, each respondent chooses 'Strongly Agree' will be scored 5, 'Agree' is worth 4, 'Neutral' is worth 3, 'Disagree' is worth 2, and 'Strongly Disagree' is worth 1 . In negative question, each respondent chooses 'Strongly Disagree' will be scored 5, 'Disagree' is worth 4, 'Neutral' is worth 3, 'Agree' is 
Students' Attitude Toward The Use of Wattpad in Reading Comprehension, Rohani Ganie, Khairunnisa Audi Miranda, Muhammad Yusuf

worth 2, and 'Strongly Agree' is worth 1 . Below is a table of the results of calculating the value of the respondent's answers:

\begin{tabular}{|l|l|l|l|}
\hline Code & $\begin{array}{l}\text { Positive } \\
\text { questions }\end{array}$ & $\begin{array}{l}\text { Negative } \\
\text { Questions }\end{array}$ & Result \\
\hline R1 & 17 & 17 & Neutral \\
\hline R2 & 24 & 22 & Positive \\
\hline R3 & 16 & 21 & Negative \\
\hline R4 & 20 & 19 & Positive \\
\hline R5 & 19 & 19 & Neutral \\
\hline R6 & 18 & 19 & Negative \\
\hline R7 & 19 & 19 & Neutral \\
\hline R8 & 19 & 17 & Positive \\
\hline R9 & 18 & 19 & Negative \\
\hline R10 & 18 & 18 & Neutral \\
\hline R11 & 20 & 18 & Positive \\
\hline R12 & 17 & 15 & Positive \\
\hline R13 & 18 & 18 & Neutral \\
\hline R14 & 21 & 20 & Positive \\
\hline R15 & 17 & 18 & Negative \\
\hline R16 & 19 & 16 & Positive \\
\hline R17 & 19 & 13 & Positive \\
\hline R18 & 20 & 18 & Positive \\
\hline R19 & 25 & 21 & Positive \\
\hline R20 & 18 & 18 & Neutral \\
\hline
\end{tabular}

Table 1. Results of the attitude assessment chosen by the respondent

From the manual calculation of the value carried out by the researchers, it is found that 10 respondents were declared to be having positive attitudes, 6 respondents were having neutral attitudes and 4 respondents were having negative attitudes towards the use of Wattpad in reading.

\section{Conclusion}

This study aimed to seek what components of reading are affected by reading Wattpad and how the students' attitudes towards the use of Wattpad for reading. There were two major conclusions drawn from the findings and discussion from the previous chapter. First, based on the results of research on 20 respondents who are students of English literature at Universitas Sumatera Utara, among the 5 reading components according to the national reading panel, namely phonemic awareness, phonics, vocabulary, fluency, and comprehension, it was found that Vocabulary is the most affected reading component because of reading Wattpad. As many as $40 \%$ of respondents in this study chose Vocabulary, $35 \%$ of respondents chose comprehension, $15 \%$ of respondents chose fluency and $10 \%$ of respondents chose phonemic awareness. Then second, after conducting research it is found that 10 respondents were declared to be having positive attitudes, 6 respondents were having neutral attitudes and 4 respondents were having negative attitudes towards the use of Wattpad in reading. 


\section{References}

(US), N. R. (2000). Report of the national reading panel; Teaching children to read: An evidence-based assesment of the scientific research literature in reading and its implications for reading instruction. In Reports of the subgroups: National Institute of Child Health and Human Development, National Institutes of Health Lockhart.

Abidin, Y. (2010). Kemampuan Berbahasa Indonesia di Perguruan Tinggi. Bandung: Maulana Media Grafika.

Alfassi, M. (2004). Reading to Learn: Effects of Combined Strategy Instruction on High School Students. The Journal of Educational Research 97(4), 171-185.

Alyousef, H. S. (2006). Teaching Reading Comprehension to ESL/EFL Learners. Journal of Language and Learning, 64.

Azwar, S. (2013). Sikap manusia: teori dan pengukurannya (edisi ke-2). Yogyakarta: Pustaka Pelajar.

Brown, H. (2001). Teaching by Principles: An Interactive Approach to Language. Pedagogy: San Francisco State University.

Coiro, J., \& Dobler, E. (2007). Reading Comprehension on the Internet: Exploring the online comprehension strategies used by sixth-grade skilled readers to search for and locate information on the internet. Reading Research Quarterly.

Cresswell, J. (2012). Educational Research: planning, conducting, quantitative and qualitative research (fourth edition). United.

Creswell, J. (2007). Qualitative Inquiry \& Research Design: Qualitative, Quantitative, and Mixed Methods Approaches (2nd ed). Thousand Oaks, CA: Sage.

Eskey D. E, and D. F. (1986). Theoritical Foundations in Teaching Reading for Academics Purposes. Massachusetts: Addison-Wesley Publishing Company.

Matthewson, G. (1994). Model of attitude influence upon reading and learning to read. In $R$. Ruddell, M. Ruddell, \& H. Singer (Eds.), Theoretical models and processes of reading (4th ed., pp. 1131-1161). Newark, DE: International Reading Association.

Mawardi, M. (2018). Merancang Model dan Media Pembelajaran. Scholaria: Jurnal Pendidikan Dan Kebudayaan, 8(1), 26-40.

McKenna, M. \&. (1990). Measuring attitude toward reading: A new tool for teachers. 43, 626-639.

Perfetti, C. (2001). Reading Skill. In International Encycopedia of the Social and Behaviornal Science. Cognitive Science Editor, W. Kintsch. The Netherlands: Kluwer.

Perloff, R. (2003). The Dynamics of Persuasion: Communcation and Attitudes in the 21st Century. New Jersey: Lawrence Erlbaum Associates.

Tarigan, H. (1985). Membaca sebagai suatu keterampilan berbahasa. Bandung: Angkasa.

Tirocchi, S. (2018). Wattpad. In C. A. Scolari (Ed.), Teen Media and Collaborative Culture . Barcelona: Universitat Pompeu Fabra, 93-97.

Wattpad. (2020). The Wattys 2020. Retrieved from https://www.wattpad.com/wattys/2020/

Wikipedia. (2021). Wattpad. Retrieved January 20, 2021, from https://en.wikipedia.org/wiki/Wattpad

Yamashita, J. (2013). Effects of Extensive Reading on Reading Attitudes in a Foreign Language. Japan: Nagoya University. 